\title{
PERAN DIPLOMASI INDONESIA DALAM KONFLIK ISRAEL-PALESTINA
}

\author{
Syarif Bahaudin Mudore ${ }^{1,2}$ \\ ${ }^{1}$ Pascasarjana Universitas Islam Negeri Sunan Kalijaga Yogyakarta \\ 2Email: syarifbmudore@gmail.com
}

\begin{abstract}
:
This article examined how Indonesian diplomacy has taken place in the Israeli-Palestinian conflict. Friction and armed clashes between Palestinian fighters and the Israeli military still occur and can even befall Palestinian civilians. Throught the history of Indonesia's closeness with Palestine, Indonesia is one of the countries actively calling for Palestinian independence with a two-state solution. The scientific relationship between Palestinian scholars and Indonesian students studying in Egypt made Palestine one of the countries that recognized Indonesia's independence with Egypt. Relations between the two countries continue today. This article is described using conflict resolution theory. Furthermore, the authors find the findings of Indonesia's diplomacy in resolving the Israeli-Palestinian conflict, Indonesia plays an active role through its role as a nonpermanent member of the UN Security Council. Even Indonesia opposed US President Donald Trump's policy on Jerusalem as the Capital of Israel and moves its embassy to Jerusalem. It is proven that Indonesia plays the role of co-sponsor, facilitator, mediator, participator, initiator, actor, motivator and justifier in helping resolve the IsraeliPalestinian conflict.
\end{abstract}

Keywords: Israeli-Palestinian Conflict, Indonesia and Diplomation

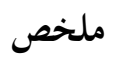

$$
\begin{aligned}
& \text { تناولت هذه المقالة أنشطة حكومة إندونيسيا الدبلوماسية في معالجة الصراع بين إسرائيل وفلسطين، الذى لم يزل } \\
& \text { قائما فن شكل الاحتكاك السلاحي بين المجاهدين الفلسطينين والجيش الإسرائيلي، بل قد يتورط فيه المدنيون من } \\
& \text { الطرفين. بفضل القرابة التاريخية بين إندونيسيا وفلسطين، طالبت إندونيسيا باستمرار على استقلال فلسطين فن }
\end{aligned}
$$

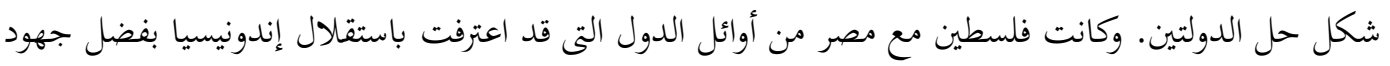

$$
\begin{aligned}
& \text { الطلاب الإندونيسيين والعلماء الفلسطينيين حينذاك، ولم تزل هذه العلاقة الطيبة قائمة إلى الحاضر. ولتحليل }
\end{aligned}
$$

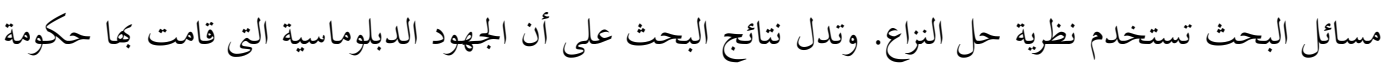

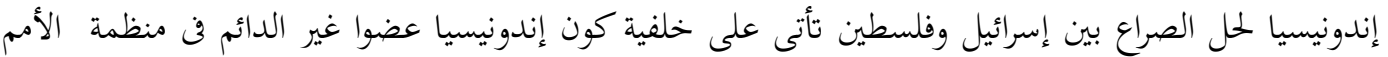

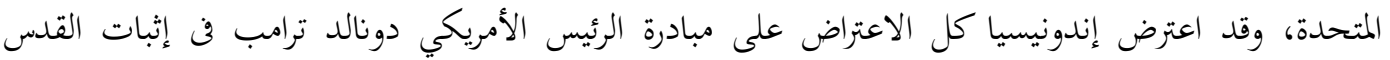

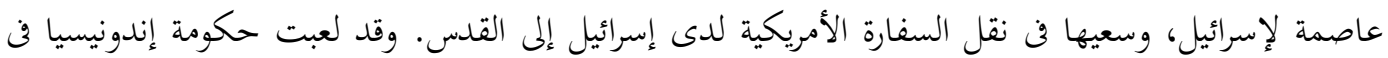

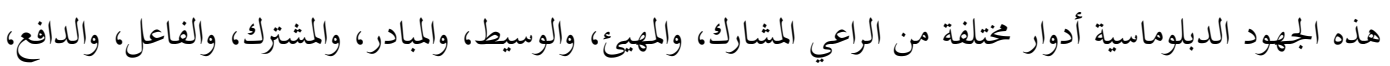

$$
\begin{aligned}
& \text { والمحكم فن السعي فن حل الصراع بين إسرائيل وفلسطين. } \\
& \text { الكلمات المفتاحية: الصراع بين إسرائيل وفلسطين، إندونيسيا، الديبلوماسية. }
\end{aligned}
$$




\section{A. Pendahuluan}

Konflik Israel-Palestina merupakan salah satu konflik Timur Tengah yang sampai saat ini menjadi sebuah konflik tak berujung dan belum menemukan titik temu. Zionisme yang dikampanyekan oleh Theodore Herzl menjadi sebuah embrio yang melahirkan sebuah negara Israel. Deklarasi negara Israel pada tahun 1948 merupakan sebuah tanda bergulirnya bola panas yang membuat orang-orang Arab tersadar. Klaim Yahudi atas tanah Palestina membuka sebuah lubang yang menganga dan siap menelan salah satu dari keduanya. Israel tidak pernah berhenti dengan upaya perluasan pemukiman Yahudi di tanah Palestina. Palestina sendiri menjadi pesakitan dan hanya mampu melawan sekuat tenaganya yang pada akhirnya tanah-tanah mereka dirampas untuk dijadikan pemukiman yahudi. Di sisi lain, wzarga negara Palestina sendiri dihadapkan pada pilihan yang tidak menguntungkan, mengungsi atau tetap bertahan dalam kekuasaan Israel yang memperlakukan mereka sebagai warga negara ke-3. Israel tidak pernah berhenti untuk mendatangkan orang-orang Yahudi ke negara mereka. Mereka menyatakan bahwa Israel adalah rumah tempat kembalinya para Yahudi setelah mereka mengalami pembantaian dan pengusiran di masa lalu.

Resistensi Israel selama ini bukan merupakan sesuatu yang aneh. Israel selalu mendapatkan restu dan dukungan dari negara 'polisi dunia' Amerika Serikat (AS). Seberapa besarpun tekanan dunia terhadap negara kecil ini, ia akan dengan leluasa mewujudkan keinginannya tanpa memikirkan kecaman-kecaman dari negara-negara di dunia yang tidak setuju dengan kebijakan dan sepak terjangnya. Seberapa banyakpun resolusi Dewan Keamanan PBB, ketika itu merugikan kepentingan Israel, Amerika akan menjadi nöegara terdepan yang mem-veto resolusi tersebut.

Sebaliknya, nasib bangsa Palestina selalu dipandang sebelah mata oleh Amerika, bahkan Israel menutup mata tentang hal ini. Perjuangan bangsa Palestina selalu mengalami kebuntuan.
Mereka dikepung oleh kepentingankepentingan global dari Amerika Serikat. Amerika sendiri memiliki sekutu Arab yang dengan mudah akan didikte sesuai keinginan Amerika. Sikap bangsa Arab terhadap nasib bangsa Palestina seolah hanya sebatas formalitas saja. Mereka tidak sungguh-sungguh memperjuangkan kemerdekaan Palestina. Sebaliknya, Indonesia mengambil peran penting dalam mendukung dan memperjuangkan kemerdekaan bagi bangsa Palestina. Sebagai negara yang mayoritas Islam dan memiliki prinsip bahwa kemerdekaan adalah hak segala bangsa, Indonesia menjadi satu negara yang memberikan perhatian khusus terkait konflik IsraelPalestina.

Tulisan ini membahas diplomasi Indonesia dalam membantu penyelesaian konflik Israel-Palestina. Tulisan ini menggunakan teori resolusi konflik untuk menguraikan peran-peran Indonesia dalam konflik kedua negara ini.

\section{B. Kerangka Teori dan Metodologi Penelitian}

Fisher menjelaskan bahwa suatu konflik bisa diselesaikan dengan tiga cara, yaitu negosiasi, mediasi dan arbitrase. Negosiasi adalah sebuah proses yang mendorong pihak-pihak yang bersengketa untuk berdiskusi mengenai pilihan-pilihan yang mungkin dicapai sehingga bisa menyelesaikan konflik yang sedang terjadi. Media adalah proses interaksi yang menggunakan bantuan pihak ketiga sehingga kedua pihak bisa mencapai kesepakatan penyelesaian konflik. Arbitrase adalah bentuk penyelesaian konflik dengan cara perwalian, yaitu memberikan wewenang kepada pihak ketiga untuk memutuskan dan menjalankan sebuah penyelesaian konflik (Fisher dkk., 2000:7-8).

Ada tiga pendekatan perdamaian resolusi konflik yang dikenalkan oleh Johan Galtung, yaitu: pemeliharaan perdamaian (peacekeeping), penciptaan perdamaian (peacemaking) dan pembangunan perdamaian (peacebuilding) (Galtung, 1976). 
Artikel ini merupakan sebuah hasil penelitian library research. Data didapatkan dengan teknik pustaka dan kemudian diolah dan dianalisis berdasarkan rumusan masalah dan teori yang digunakan. Sumber data yang digunakan adalah beberapa jurnal, buku dan berita terpercaya yang membahas konflik Israel-Palestina. Penyajian data dan hasil penelitian disajikan dengan cara deskriptif analitis.

\section{Pembahasan}

\section{Israel-Palestina Sebelum Deklarasi Negara Israel 14 Mei 1948}

Sejak abad ke-16, Palestina merupakan sebuah wilayah yang berada di bawah kekuasaan Turki Utsmani (Hermawati, 2005:130). Memasuki akhir abad ke-19, yakni pada tahun 1897, usaha untuk mendapatkan legitimasi atas bangsa Yahudi dan mendelegitimasi bangsa Arab pada tanah Palestina dilakukan oleh kelompok Zionis dengan cara melobi langsung Sultan Abdul Hamid II. Usulan yang lebih berani adalah mereka meminta Sultan Abdul Hamid II untuk hak bagi kaum Yahudi untuk mengusir penduduk asli (Maulani, 2002:17). Sejak saat itu, rongrongan kaum Zionis terhadap Kekhalifahan Turki Utsmani tetap berlanjut demi mendapatkan tanah khusus sebagai pemukiman bagi bangsanya dan kelak akan dijadikan sebagai negara Yahudi. Namun, Kekhalifahan tetap teguh tidak mengabulkan permintaan itu. Lobi langsung terhadap Kekhalifahan tidak membuahkan hasil apapun. Akhirnya kaum Zionis melobi Inggris untuk memuluskan keinginannya. Inggris menawarkan tanah di Uganda atau Amerika latin, tapi kaum Zionis menolaknya. Mereka memandang tanah Palestina adalah tanah yang dijanjikan untuk bangsa Yahudi sebagai pewaris sah dari tanah tersebut (Noor, 2014: 325). Theodore Herzl, pencetus gerakan freemasonry menulis sebuah artikel Der Judenstaat (Negara Yahudi) pada tahun 1896. Zionisme politis mulai dikumandangkan melalui tulisan ini. Pada tahun 1897, kaum Zionis menggelar sebuah kongres Zionis pertama di Basel,
Swiss yang berbicara tentang pendirian sebuah negara Yahudi dan menjadikan dunia sebagai budak Zionis serta mengambil Al Quds sebagai Ibukota Pemerintahan Negara Zionis (Noor, 2014:321). Bahkan Herzl menyatakan bahwa Zionisme adalah jawaban atas semua penderitaan yang telah dialami oleh bangsa Yahudi, sudah saatnya bangsa Yahudi hidup dengan aman dan tenang di sebuah tanah warisan leluhur mereka (Sihbudi, 2007:323).

Gelombang pertama pengungsi Yahudi telah masuk ke tanah Palestina dalam kurun waktu 1881-1903. Gelombang pengungsi selanjutnya terjadi dalam kurun waktu 1904-1924 yang datang dari bangsa Yahudi Uni Soviet (Sihbudi, 2007:459-460).

Ketika Perang Dunia I selesai, Zionis menjadi pihak yang diuntungkan karena Turki Utsmani mengalami kekalahan. Mereka mendapat ruang bebas untuk memuluskan keinginannya. Pada tahun 1916, terbentuk sebuah perjanjian Sykes-Picot antara Inggris-Rusia-Prancis sebagai alat untuk mencengkeram Dunia Arab dan membagi-bagi wilayah Turki Utsmani agar mereka bisa melepaskan diri dari Kekhalifahan (Friedman, 1990). Selain itu, pada tahun 1917, Menteri Luar Negeri Inggris, Arthur James Balfour, memberikan sebuah jaminan terhadap cita-cita Yahudi tersebut melalui Pemimpin komunitas yahudi di Inggris, Lord Rothschild. Dalam Deklarasi Balfour, dinyatakan bahwa Inggris siap menjamin dan membantu kaum Zionis dalam mewujudkan sebuah Negara Yahudi (Noor, 2014:327-328). Hingga akhirnya pada tahun 1923 Inggris mendapat mandat dari Liga BangsaBangsa untuk menguasai tanah Palestina. Semenjak saat itu terjadi pertentangan antara bangsa Arab dan bangsa Yahudi di sana.

Gelombang pengungsi Yahudi keempat kembali terjadi yaitu pada kurun waktu 1924-1928. Mereka merupakan kelompok bangsa Yahudi kelas menengah Eropa Timur dan Uni Soviet (Sihbudi, 2007: 460). Pada tahun 1929 terjadi kerusuhan antara kaum Zionis dan 
Palestina tepatnya di Tembok Barat. Kerusuhan yang berlangsung selama seminggu ini menewaskan 115 orang Arab dan 133 orang Yahudi. Pada tahun 1933, Adolf Hitler mulai berkuasa di Jerman. Ia merumuskan sebuah undang-undang yang berisi diskriminasi atas bangsa Yahudi. Hingga tahun 1935, gelombang pengungsi Yahudi semakin meningkat, banyak bangsa Yahudi yang melarikan diri dan mengungsi ke luar negeri terutama ke Amerika Serikat (Sihbudi, 2007:460).

Pada tahun 1936, terjadi revolusi Arab di Palestina terhadap penguasa Inggris di sana. Namun, kaum Zionis membantu Inggris dalam meredam pemberontakan ini. Akibatnya, mereka mengusir para pemberontak dan mengeksekusi para pimpinannya. Sebaliknya, pada kurun waktu 1936-1939 penyiksaan terhadap bangsa Yahudi di Jerman semakin meningkat dan berkelanjutan. Semenjak terjadi revolusi Arab, dalam laporan British Peel Commission terdapat usulan pembagian wilayah Palestina ke dalam dua wilayah yaitu wilayah Yahudi dan Arab. Hal ini menyulut kemarahan bangsa Arab.

$$
\text { Ketika Perang Dunia II }
$$

berkecamuk, Adolf Hitler memandang bahwa kekalahan Jerman pada Perang Dunia I merupakan sebab dari pengkhianatan bangsa Yahudi yang bekerja sama dengan pihak sekutu. Oleh karena itu Hitler menyebarkan paham anti-semitisme di Jerman dan wilayahwilayah kekuasaannya. Sebuah endivsung (Penyelesaian akhir) atas bangsa Yahudi pun tidak bisa dielakkan. Enam juta jiwa bangsa Yahudi, jutaan bangsa slavia, kaum homoseksual, Roma dan "kelompok yang tak diinginkan" menjadi korban kekejaman Nazi pimpinan Hitler. Cerita inilah yang dijadikan alat oleh kaum Zionis untuk menarik simpati dunia dalam mewujudkan pendirian negara Yahudi (Sihbudi, 2007:460).

Pada tahun 1939 terjadi ketegangan antara Zionis dan penguasa Inggris di Palestina. Dalam British MacDonald White Paper direkomendasikan pembatasan imigran Yahudi, pembelian tanah dan menuntut pendirian dua negara merdeka dalam sepuluh tahun. Hal ini menyulut kemarahan bangsa Yahudi sehingga mereka memutuskan aliansi Inggris-Zionis mereka. Pada puncaknya, kelompok militan Yahudi pimpinan Menachim Begin mendeklarasikan perang terhadap Inggris di Palestina.

Seiring berakhirnya Perang Dunia II pada tahun 1945, PBB didirikan dan masih banyak bangsa Yahudi yang terlantar dan tidak memiliki tempat tinggal. Mereka adalah bangsa Yahudi Eropa Timur dan Tengah. Pada tahun selanjutnya PBB mendapat rekomendasi dari Anglo-American Commission of Inqury mandat atas tanah Palestina. Namun, di Palestina sendiri terjadi kekerasan dari Palestina dan Yahudi terhadap Inggris satu sama lain. Pada tahun ini juga masih terjadi pelarian bangsa Yahudi ke Palestina melalui ruterute gelap dan bawah laut. Pada tahun 1947, Inggris meminta penanganan PBB atas tanah Palestina sekaligus merekomendasikan pembagian tanah Palestina kepada bangsa Arab dan Yahudi, sedangkan Yerussalem sendiri berada dalam pengawasan PBB (Hermawati, 2005:134).

Inggris mengakhiri mandatnya atas tanah Palestina pada tahun 1948. Pada tanggal 14 Mei 1948, sehari sebelum berakhirnya mandat Inggris, kaum Zionis mendeklarasikan berdirinya negara Israel sebagai negara Yahudi (Friedman, 1990). Hal ini mendapat penentangan dari bangsa Arab, mereka mengecam dan menyatakan perang terhadap Israel. Israel sendiri mendapatkan kekuasaan $77 \%$ tanah Palestina yang mereka dapatkan dari mandat Inggris. Yerussalem terbagi ke dalam beberapa bagian. Orang-orang Palestina yang terlantar selama dan sesudah perang tidak diizinkan kembali ke rumah mereka. Padahal PBB sudah mendukung hak pengungsi Palestina melalui resolusi PBB nomor 194 untuk kembali ke rumahnya dan mereka berhak mendapatkan kompensasi ketika mereka enggan kembali (Garaudy, 2000:112113). Saat itu, masih banyak orang-orang 
Palestina yang bertahan di negara baru yang bernama Israel.

\section{Perjalanan Konflik Israel-Palestina 1948-2017}

Tahun 1948-1958 merupakan tahun gelombang besar imigrasi Yahudi ke Palestina. Imigran Yahudi yang berasalah dari Eropa, Afrika Utara dan Asia berhasil didatangkan oleh Israel ke tanah Palestina yang mereka klaim sebagai negara Israel. Pada tahun 1949, terjadi gencatan senjata antara tentara Israel dengan Negara-Negara Arab (BBC News, 2014). Pada tahun 1950, Israel melakukan penyitaan terhadap hak milik bangsa Arab dalam skala luas. Mereka menetapkan Undang-Undang tentang Hak Kembali dan Menetap di daerah asal bagi Yahudi. Gerakan-gerakan Zionis semakin meningkat dan menunjukkan kekejamannya atas bangsa Arab. Pada tahun 1956-1957 terjadi perang Suez antara Israel dan Mesir. Israel mendapatkan bantuan dari Inggris dan Prancis sehingga ia bisa menang, tapi ia tetap mundur dari Sinai dan Jalur Gaza.

Pada tahun 1964, Liga Arab membentuk Palestine Liberation Organization (PLO) sebagai wadah perjuangan rakyat Palestina dalam menghadapi Israel. PLO-lah satu-satunya organisasi yang dianggap sah dalam memperjuangkan kemerdekaan Palestina. Pendirian organisasi ini juga dalam rangka menjaga kepentingan masing-masing negara Arab. Kekhawatiran mereka akan munculnya organisasi-organisasi yang merusak stabilitas wilayah Arab mendorong pendirian PLO. PLO juga dirancang untuk membawahi gerakangerakan perjuangan rakyat Palestina menuju kemerdekaan. Pada awalnya, pendirian PLO ini tidak mendapatkan antusiasme dari rakyat Palestina. Mereka berpandangan bahwa organisasi ini hanya akan menjadi simbol tanpa hasil yang efektif (Sihbudi, 1993:76). Namun, seiring berjalannya waktu, banyak organisasiorganisasi perjuangan rakyat yang bergabung ke dalam naungan PLO. Organisasi-organisasi perjuangan rakyat Palestina yang berada di bawah naungan PLO adalah Fatah, Front Rakyat untuk
Pembebasan Palestina, Front Demokratik untuk Pembebasan Palestina, Front Rakyat untuk Pembebasan Palestina-Komando Umum, al Saiqah, Front Pembebasan Arab dan yang lainnya (Sihbudi, 1993:76). Ketika PLO dipimpin oleh Yasser Arafat, dia berhasil menaikkan citranya di mata dunia. Dunia pun menganggap PLO sebagai otoritas sah atas perjuangan rakyat Palestina. PLO lah wakil rakyat Palestina yang sah (Sihbudi, 1993:76).

Pada tahun 1967, Israel melakukan tindakan pencegahan yakni dengan menyerang Tepi Barat, Jalur Gaza (Friedman, 1990:218), Gurun Sinai di Mesir dan Dataran Tinggi Golan di Syria. Mereka berhasil menguasai wilayahwilayah tersebut. Selain itu, Israel juga meluaskan perbatasan Yerussalem. Bahkan ia memasukkan daerah pendudukannya ke dalam wilayah administrasinya. Pada tahun ini juga PBB mengeluarkan resolusi yang menuntut Israel menarik pasukannya dari wilayah yang baru didudukinya. Pada tahun 1968, Israel melakukan pembangunan perkampungan Yahudi di wilayah-wilayah yang baru didudukinya. Pada tahun 1969, Yasser Arafat dari faksi Fatah terpilih menjadi Pimpinan PLO yang bermarkas di Yordania. Namun pada tahun 1970 terjadi perang sipil antara Palestina dan Yordania sehingga berakibat pada pengusiran PLO dari Yordania. Pada akhirnya markas PLO dipindahkan ke Lebanon. Faktor pengaruh AS terhadap Yordania menjadi salah satu pemicu dalam pengusiran PLO dari Yordania. Pada Oktober 1973, Mesir dan Syria menyerang Israel di Sinai dan Dataran Tinggi Golan. Mereka hampir mampu memukul mundur Israel, tapi AS membantu Israel. Sehingga Anwar Sadat selaku pemimpin Mesir memilih untuk berkompromi dengan mereka. DK PBB mengeluarkan resolusi nomor 338 yang berisi gencatan senjata dan sidang perdamaian menyeluruh.

Pada tahun 1974, Yasser Arafat berpidato di PBB dan ia berhasil menarik simpati dunia serta mendorong dunia untuk mengakui PLO sebagai wakil sah rakyat Palestina. Kekuatan Amerika Serikat (AS) di balik kepentingan Israel 
semakin tampak dan muncul ke permukaan. Pada tahun 1975 mereka berjanji kepada Israel bahwa mereka tidak akan bersedia berbicara dengan PLO hingga ia mengakui resolusi $\mathrm{PBB}$ nomor 242 dan 338. Pada pemilu tahun 1976, para kandidat PLO memenangkan pemilihan tingkat kotamadya di Tepi Barat. Pada tahun selanjutnya, partai Likud memenangkan Pemilu di Israel. Menachim Begin berhasil menjadi Perdana Menteri.

Dalam kurun waktu 1978-1985 terjadi peristiwa-peristiwa penting seputar Israel-Palestina-Lebanon-Syiria-Mesir.

Pada tahun 1978, Israel melakukan invasi ke wilayah Lebanon Selatan. Pada tahun ini juga Sadat, Begin dan Presiden Jimmy Carter melakukan penandatanganan Perjanjian Camp David. Di tahun selanjutnya Mesir dan Israel melakukan perjanjian perdamaian Mesir-Israel di Washington. Israel kembali berulah dengan menganeksasi Yerussalem Timur melalui undang-undangnya tentang aneksasi Yerussalem. Hal ini mengundang kecaman dari PBB. Pada tahun 1981 terjadi gencatan senjata antara Israel dengan PLO hingga juni 1981. Namun, terjadi aneksasi Israel atas Dataran Tinggi Golan milik Syria. Di tahun selanjutnya, 1982, Israel menginvasi Lebanon yang berakibat pada pemindahan markas PLO ke Tunisia. Pada tahun ini terjadi pembantaian di Sabra dan Shatila (Garaudy, 2000:124). Pelanggaran ini gagal dibawa ke forum internasional karena veto dari AS. Sikap AS ini membuat Israel semakin berani. Pada tahun 1984, Israel melaksanakan Pemilu awal yang memisahkan pemerintaha koalisi Knesset dan Labor-Likud. Di tahun selanjutnya Israel menarik diri dari sebagian wilayah Lebanon, tapi mereka tetap menyisakan pasukan Lebanon yang berkoalisi dengan Israel. Pada tahun ini juga markas besar PLO di Tunisia dibom oleh Israel.

Terjadi gelombang intifadha Palestina tanpa kekerasan pada kurun waktu tahun 1987-1993. Pada tahun 1988, pemilu di Israel mengakibatkan terbelahnya Knesset dan National Unity
Government. Pertemuan Dewan Nasional Palestina mendeklarasikan Negara Palestina di Aljazair. Pada akhirnya Arafat menerima resolusi PBB nomor 242 dan 338 yang berimplikasi pada dibukanya dialog dengan Amerika. Selain itu, Arafat mengakui eksistensi negara Israel. Kementerian Luar Negeri menerbitakn laporan yang sangat kritis tentang praktek HAM di Israel pada tahun 1989. Pada tahun ini pula terjadi demontrasi perjanjian Internasional yang besar di Yerussalem. Tahun selanjutnya, 1990, Pemerintah Koalisi Israel tumbang setelah diusulkannya negosiasi dengan Palestina. Terjadi Imigrasi dari negara-negara bekas Uni Soviet ke Israel. Yitzhak Shamir membentuk Pemerintahan sayap kanan yang terbatas, yang dipimpin oleh Likud, sedangkan Amerika menunda dialog dengan PLO (Sihbudi, 2007:462-463).

Pada 1991, digelar konferensi perdamaian internasional Arab-Israel di Madrid. Palestina dimasukkan ke dalam delegasi bersama Yordania-Palestina. Pada tahun 1992, jalur diplomasi IsraelPalestina terus berlangsung. Di sisi lain, Pemilu Israel memenangkan partai Buruh dan menjadikan Yitzhak Rabin sebagai Perdana Menteri. Taun 1993, Israel membatasi ruang gerak Palestina. PLO dan Israel melakukan penandatanganan Perjanjian Oslo yang berisi tentang susunan pemerintahan sendiri yang sementara. Terjadi pembantaian orang Palestina di masjid Hebron oleh seorang pemukin Israel bernama Baruch Goldstein. Lahir Persetujuan Kairo tentang implementasi Perjanjian Oslo. Selanjutnya Arafat mendirikan markas bersa Otoritas Palestina di Gaza. Pada tahun ini pula Yordania dan Israel menandatangani perjanjian damai (Sihbudi, 2007:463). Pada tahun 1995 Perjanjian Oslo II menerapkan pembagian pengawasan Tepi Barat dalam tiga bentuk yaitu: Area A untuk pengawasan langsung Palestina, Area B untuk Pengawasan sipil Palestina dan Israel dan Area C untuk pengawasan Israel. Pada tahun ini, Rabin dibunuh oleh seorang Yahudi bernama Yigal Amir di Tel Aviv. 
Tahun 1996 merupakan pemilu pertama bagi rakyat Palestina untuk pemilihan Presiden dan Parlemen. Arafat keluar sebagai Presiden. Di sisi lain Benyamin Netanyahu terpilih sebagai Perdana Menteri Israel. Pada tahun 1997, pembagian Kota Hebron menjadi wilayah Palestina dan Israel. Israel kembali membangun pemukiman Har Homa untuk bangsa Yahudi yang terletak di antara Yerussalem dan Betlehem. Pada tahun 1998, PLO menolak klausul anti-Israel dalam konstitusi PLO. Setahun kemudian Ehud Barak terpilih sebagai Perdana Menteri Israel (Sihbudi, 2007:463).

Tahun 2000 merupakan tahun dimana Otoritas Palestina mendapat kontrol langsung atau tidak langsung atas $40 \%$ wilayah Tepi Barat dan $65 \%$ wilayah Gaza. Pada tahun ini pertemuan puncak Camp David mencapai kegagalan. Bangsa Palestina melakukan pemberontakan besar-besaran sebagai reaksi kunjungan Ariel Sharon ke al Haram as Syarif dengan kawalan 1000 pasukan bersenjata. Pada tahun 2001 konflik Israel-Palestina kian memanas. Kelompok garis keras Palestina melakukan bom bunuh diri ke militer dan sipil Israel. Sebaliknya, pasukan Israel meningkatkan target pembunuhan orang Palestina dan serangan udara di wilayah kekuasaan Palestina. Ariel Sharon terpilih sebagai Perdana Menteri pada tahun ini. AS sendiri menyerukan gencatan senjata dan pembekuan sepenuhnya atas pemukiman Yahudi di Tepi Barat dan Jalur Gaza. Bom bunuh diri Palestina dan Target Pembunuhan Israel masih terus berlanjut di tahun 2003. Pada tahun 2002 Israel kembali memaksa menduduki kembali wilayah yang telah ia tinggalkan. Israel membangun tembok keamanan di Tepi Barat. Di sisi lain, Arafat menjadi tahanan rumah di Ramallah. Pada akhirnya Liga Arab mendesak untuk mengakui negara Israel, dengan harapan pendudukan Israel atas Palestina dihentikan. Uni Eropa, AS, Rusia dan PBB mengajukan 'Peta Jalan' damai untuk kedua negara (Sihbudi, 2007:464).

Pada tahun 2003, Mahmud Abbas terpilih sebagai Perdana Menteri Palestina.
Namun, tidak lama ia mengundurkan diri dan digantikan oleh Ahmad Qurei. Sebaliknya, Israel kembali menyelesaikan pembangunan tembok keamana di Tepi Barat. Pada 11 November 2004, Yasser Arafat meninggal dunia dalam usia 75 tahun. Ia dimakamkan di Ramallah. Pada 10 Januari 2005, Mahmud Abbas ditetapkan sebagai pemenang Pemilu Presiden. Pada 19 Agustus, Jalur Gaza dibersihkan dari pemukim Yahudi. Terjadi kemelut di dalam tubuh politik Israel, pada 10 November Amir Perez mangalahkan Shimon Peres dalam pemilihan ketua partai Buruh. Ia pun menarik partainya dari koalisi. Kemudian pada 21 November, Ariel Sharon mundur dari ketua Partai Likud dan mendirikan partai tengah dengan nama Kadima. Selanjutnya, Shimon Peres mengundurkan diri dari partai Buruh dan bergabung dengan partai baru Ariel Sharon. Pada pertengahan Desember 2005, Ariel Sharon terkena stroke dan dirawat di Rumah Sakit. Kian hari, sakit yang diderita Ariel Sharon bertambah parah. Pada akhirnya kekuasaannya diberikan kepada Ehud Olmert. Pada 26 Januari 2006, Hamas memenangkan pemilu Palestina. Ismail Haniya ditunjuk sebagai pemimpin Hamas sepeninggal Syaikh Ahmad Yasin.

Pada tahun 2007, Israel memperketat kontrol atas Jalur Gaza setelah Hamas memaksa keluar kelompok pesaing, Fatah, dari Jalur Gaza. 27 Desember 2008-17 Januari 2009, Israel dan Hamas saling menyatakan gencatan senjata. Pada tahun 2010, pemerintah Israel melonggarkan pembatasan yang mulai diterapkan pada 2007 setelah masyarakat internasional menyimpulkan krisis kemanusian di Gaza memburuk. Pada tanggal 29 November 2012, Negara Palestina resmi disahkan sebagai nonmember observer state PBB melalui resolusi Majelis Umum PBB No. 67/19 (Kementerian Luar Negeri Republik Indonesia 2019a).

Sejak 2007, Hamas dan Fatah mengalami perpecahan dalam mencapai Palestina merdeka. Namun, pada 2014, keduanya sepakat melakukan rekonsiliasi sementara (al-mushaalahahi). Menurut 
Burdah, rekonsiliasi ini harus menjadi modal penting untuk keduanya sebagai kekuatan untuk perjuangan Palestina (Burdah, 2014:93). Pada Juli 2014, Israel melakukan agresi militer ke wilayah Jalur Gaza. Pada 26 Agustus 2014, berlaku gencatan senjata tidak terbatas antara Israel dan Palestina (BBC News, 2014). 30 Oktober 2014, Israel menutup masjid Al-Aqsa sebagai reaksi atas penembakan rabi Yehuda Glick (Purnamasari, 2017). Namun, keesokan harinya Israel mengumumkan membuka Masjid Al-Aqsa untuk umat Islam setelah adanya seruan dari Arab dan Amerika Serikat. Bentrok Pasukan Israel-warga Palestina tidak pernah berujung. Pada 26 Juli 2015, sebanyak 19 penjaga Masjid Al-Aqsa bentrok dengan pasukan Israel. Mereka menyerbu masuk ke dalam masjid saat bentrok dengan warga Palestina. Umat Muslim marah lantaran dibuka akses masjid bagi Yahudi untuk merayakan Tisha B'av. Di tahun 2015 ini terjadi peningkatan kekerasan di Yerussalem terutama pada akhir tahun ini.

Kabar mengejutkan dari konflik Palestina adalah pernyataan Presiden Amerika, pada hari Rabu, tanggal 6 Desember 2017, Donald Trump mengakui secara sepihak bahwa Yerussalem adalah Ibukota Israel (Kementerian Luar Negeri Republik Indonesia 2019a). Selain itu, Amerika berniat memindahkan kedutaannya dari Tel Aviv ke Yerussalem. Pernyataan ini mengundang kecaman dari dunia Internasional baik di Eropa, Asia dan Indonesia. Kabar ini sontak membuat goncangan di beberapa belahan dunia, terutama di Negara-negara yang memiliki penduduk muslim yang relatif banyak. Indonesia sendiri menjadi aktor penting dalam menghadapi kabar ini.

Pada hari ulang tahun kemerderkaan Israel yang ke-70, 14 Mei 2019, AS meresmikan gedung kedutaannya di Yerussalem. Presiden Trump tidak hadir langsung untuk meresmikan kedutaan tersebut. Pejabatpejabat Amerika yang hadir diantaranya adalah Menteri Keuangan Amerika, Duta Besar Amerika untuk Israel, Duta Besar Amerika untuk Timur Tengah, putri
Donald Trump, Ivanka Trump dan suaminya, Jared Kushner.

\section{Peran Diplomasi Indonesia dalam Konflik Israel-Palestina}

Indonesia selalu terdepan dalam membela hak-hak kemanusiaan warga Palestina. Posisi Indonesia dalam konflik Israel-Palestina memiliki posisi yang strategis dalam menengahi konflik yang terus memanas antara Israel dan Palestina. Selain dikarenakan sama-sama sebagai penganut agama Islam, cita-cita mulia Negara Indonesia yang tertuang dalam Pembukaan UUD 1945 yang menyatakan bahwa kemerdekaan adalah hak segala bangsa, menjadikan Indonesia sebagai bangsa yang akan selalu mendukung dan membantu menyokong kemerdekaan sebuah bangsa yang tertindas selama ini. Selain itu, diplomasi Indonesia sendiri merupakan salah satu cara yang ditempuh untuk memperkuat dan mempertahankan komunikasi dengan Negara-negara berkembang.

Hubungan Indonesia dan Timur Tengah ditandai dengan hubungan pendidikan. Sejak masa sebelum kemerdekaan, banyak pemuda Indonesia yang berangkat ke Timur Tengah, baik Mesir maupun Arab untuk melakukan pencarian ilmu kepada Ulama-ulama di sana. KH. Hasyim Asy'ari dan KH. Ahmad Dahlan merupakan dua tokoh yang menimba ilmu ke sana dan kemudian keduanya menjadi sosok yang dihormati dan disegani di kalangan masyarakat Indonesia.

Sejarah mengatakan bahwa hubungan erat Indonesia dan Palestina sudah terjalin semenjak sebelum kemerdekaan. Hal ini ditandai oleh beberapa kaum muda yang belajar ke Timur Tengah dan bertemu dengan syaikh-syaikh dari Palestina, yaitu seperti Kahar Mudzakkir yang belajar ke Mesir dan bertemu dengan Sayyid Amin al Husaini. Syeikh inilah yang memberikan respon baik dengan memberikan ucapan selamat kepada bangsa Indonesia ketika ia mendengar kabar kemerdekaan Indonesia (Hakiem, 2017). Palestina dan Mesir merupakan dua negara pertama yang mengakui kemerdekaan Negara Indonesia. 
Pada saat itu, Indonesia sangat membutuhkan sebuah pengakuan demi langgengnya sebuah negara. Dari sinilah Indonesia mampu mempertahankan kemerdekaannya dengan berbagai perjuangan dan pengorbanan.

Dengan menganut politik luar negeri yang bebas aktif, Indonesia menempatkan diri sebagai bangsa yang menolak sebuah penjajahan dan penindasan atas rakyat palestina. Berbagai upaya perjuangan hak-hak rakyat Palestina telah banyak dilakukan oleh pemerintah Indonesia di arena internasional yaitu PBB (Sihbudi, 1997:146).

Pada saat Indonesia memiliki status anggota tidak tetap DK PBB (20072008), Indonesia selalu berupaya dalam memperjuangkan perlindungan dan penjaminan hak-hak rakyat Palestina melalui badan perdamaian dunia, PBB (Kementerian Luar Negeri Republik Indonesia t.t.). Dalam ranah PBB Indonesia memiliki peran aktif dalam memprioritaskan konflik Israel-Palestina. Sebagai anggota Dewan HAM, Indonesia mendorong diselenggarakannya sebuah Special Session Dewan HAM yang dilaksanakan pada 9 Januari dan 12 Januari 2009. Indonesia pernah menjadi salah satu Negara penggagas utama Sidang Khusus Majelis Umum PBB pada tanggal 15-16 Januari 2009 yang berbicara tentang isu Palestina (Kementerian Luar Negeri Republik Indonesia t.t.).

Pada 29 November 2012, Negara Palestina secara sah diperhitungkan sebagai non-member observer state PBB melalui co-sponsor dari Indonesia (Kementerian Luar Negeri Republik Indonesia 2019a). Ketika Konferensi Asia-Afrika diselenggarakan di Indonesia, KAA ini menghasilkan sebuah deklarasi dukungan untuk Palestina. Deklarasi tersebut disebut dengan Declaration on Palestine (Kementerian Luar Negeri Republik Indonesia t.t.). Selanjutnya, Indonesia menjadi Negara co-sponsor juga dalam sebuah moment penting bagi Negara Palestina, yaitu dalam upacara histori penaikan bendera Palestina di Markas Besar PBB di New York tepatnya pada tanggal 30 September 2015 (Kementerian Luar Negeri Republik Indonesia 2019a). Pada 14-15 Desember 2015, Indonesia menjadi tuan rumah International Conference on the Question of Jerusalem yang diselenggarakan bersama dengan OKI dan United Nations Committee on the Inalienable Rights of the Palestinian People.

Dalam membangun komunikasi dengan Israel, Indonesia memilih untuk tidak membuka jalur diplomasi dengan Israel. Isu pembukaan jalur diplomasi Indonesia-Israel sempat mencuat tatkala Indonesia dipimpin oleh Presiden Soeharto melalui tokoh NU saat itu, Abdurrahman Wahid (Sihbudi, 1997:135; Suhartiningtyas, 2014:842). Namun, isu tersebut tidak pernah terjadi sampai saat ini. Hal ini dikarenakan Indonesia sebagai pengecam segala bentuk penjajahan tidak akan membuka jalur diplomasi dengan Israel sebelum mereka rela mengakui keberadaan Negara Palestina yang merdeka berdaulat (Sihbudi, 1997:146), karena Indonesia sendiri merupakan salah satu Negara yang mendukung two state solution (Kementerian Luar Negeri Republik Indonesia 2019a).

Indonesia mengambil langkah cepat dalam merespon sebuah pernyataan kontroversial dari seorang Presiden Amerika, Donald Trump. Presiden Jokowi menugaskan Menteri Luar Negerinya untuk segera meluncur ke Yordania, Lebanon, Eropa dan Turki (Ramdhani 2017). Indonesia langsung mengutuk pernyataan sepihak Donald Trump yang menghambat sebuah cita-cita perdamaian dua Negara. Tidak hanya menteri luar negeri, Presiden Joko Widodo juga ikut serta dalam sebuah konferensi luar biasa OKI di Istanbul, Turki.

Peran diplomatik dalam konflik Israel-Palestina ini tidak hanya dilakukan oleh aktor pemerintahan saja. Namun, di Indonesia, gelombang protes langsung bermunculan dan aksi-aksi solidaritas Palestina guna mengecam pernyataan Trump terkait Yerussalem. Aksi-aksi yang dilakukan oleh rakyat Indonesia merupakan bentuk dukungan moral bangsa Indonesia atas penderitaan yang 
menimpa rakyat Palestina (Media Indonesia 2017).

Rabu, 13 Juni 2018, seorang tokoh organisasi Nahdlatul Ulama, Yahya Cholil Tsaquf, memberikan sebuah kuliah umum yang diselenggarakan oleh Trumane Institute. Selain itu, beliau juga didaulat menjadi pembicara dalam forum American Jewish Committee (AJC) Global Forum. Dalam pidatonya, beliau menyatakan bahwa kehadirannya di sana adalah untuk Palestina. Selain itu, beliau menyatakan bahwa kehadirannya di sana bukanlah sebagai wakil negara atau Nahdlatul Ulama, melainkan sebagai inisiatif pribadi. Beliau menyadari akan reaksi masyarakat dunia dengan langkahnya tersebut. Langkah ini dianggap kontroversial karena dianggap telah mencederai perjuangan rakyat palestina dalam mendapatkan kemerdekaan. Tidak sedikit pihak yang mengecam langkah beliau ini.

Indonesia menyatakan posisinya dalam menyikapi kebijakan Amerika yang mengakui Jerusalem sebagai ibukota Israel dan pemindahan kedutaan AS ke Jerusalem dengan mengecam keras kebijakan tersebut. Indonesia menilai langkah ini sebagai bentuk pelanggaran resolusi Majelis Umum dan Dewan Keamanan PBB dan bisa mengancam proses perdamaian. Indonesia mengajak negara-negara anggota PBB untuk tidak mengikuti langkah kebijakan Amerika Serikat. Pemerintah dan rakyat Indonesia selalu bersama dengan rakyat Palestina dalam memperjuangkan kemerdekaan dan hak-haknya (Kementerian Luar Negeri Republik Indonesia 2019a).

Pembangunan pemukimanpemukiman Yahudi oleh pemerintah Israel mendapat sorotan dari Pemerintah Indonesia. Secara aktif Indonesia menegaskan bahwa langkah tersebut adalah langkah illegal. Di hadapan anggota Dewan Keamanan PBB, Menteri Luar Negeri Indonesia, Retno Marsudi menyatakan bahwa langkah pembangunan pemukiman illegal di wilayah palestina termasuk di Yerusalem timur akan semakin memudarkan harapan solusi dua negara. Pembangunan ini merupakan sumber dari berbagai pelanggaran hukum dan HAM terhadap rakyat Palestina. Selanjutnya, Menlu menyatakan bahwa masyarakat internasional memiliki tanggung jawab untuk menghentikan kebijakan pembangunan pemukiman illegal oleh Israel (Kementerian Luar Negeri Republik Indonesia 2019b).

Beberapa bentuk dukungan konkret Indonesia untuk Palestina adalah penguatan dukungan negara-negara AsiaAfrika untuk kapasitas Palestina melalui peringatan 60 tahun Konferensi AsiaAfrika (KAA). Indonesia juga menjadi tuan rumah International Conference on the Question of Jerusalem sebagai kerja sama anatara OKI dan United Nations Committee on Inalienable Rights of the Palestinian People. Pada 6-7 Maret 2016, Indonesia menjadi tuan rumah KTT Luar Biasa OKI yang ke-5 yang membahas tentang isu Palestina dan Al-Quds AshSharif, pertemuan ini adalah bentuk pengembangan penyelesaian konflik Israel-Palestina yang tak kian selesai (Kementerian Luar Negeri Republik Indonesia 2019a).

Bantuan lain yang diberikan oleh Pemerintah Indonesia adalah pelatihan dan pengembangan kapasitas bagi 1.257 warga Palestina, pemberian pelatihan di bidang infrastruktur, teknologi, informasi, pariwisata, light manufacturing dan pertania senilai USD 1,5 juta, bantuan untuk pembangunan Indonesian Cardiac Center di rumah sakit As-Shifa di Gaza. Bahkan Indonesia aktif memberikan kontribusi untuk UNRWA (United Nationson Relief and Works Agency for Paletine Refugees) dalam kurun waktu 2009-2014 (Kementerian Luar Negeri Republik Indonesia 2019a).

Melalui kementerian Luar Negeri,
Indonesia menyatakan bagaimana posisinya dalam menghadapi dan menyelesaikan konflik yang terjadi antara Israel dan Palestina (Kementerian Luar Negeri Republik Indonesia t.t.), yaitu:

1. Mendukung solusi dua negara (Israel dan Palestina), berdasarkan hukum internasional dan HAM, dan agar kedua belah pihak mematuhi 
parameter yang telah dibentuk dalam sejumlah resolusi $\mathrm{PBB}$.

2. Menekankan perlunya sikap berimbang (imparsial) dari masyarakat internasional dalam membantu penyelesaian masalah Palestina dan mendorong proses perdamaian.

3. Mendukung pentingnya menjaga keberlangsungan kerja UNRWA (United Nations Relief and Works Agency for Palestine Refugees in the Near East) untuk memberikan pelayanan kepada para pengungsi Palestina, serta ikut menyerukan perlunya keterlibatan masyarakat internasional dalam membantu para pengungsi Palestina, terutama dalam menjamin masa depan anakanak.

4. Indonesia secara konsisten menyampaikan komitmennya untuk membantu penyelesaian konflik yang berkepanjangan antara Palestina dan Israel.

\section{Penutup}

Konflik berkelanjutan IsraelPalestina telah memakan waktu lebih dari setengah abad tanpa kejelasan akhir cerita. Sikap keras kepala Israel telah mampu mengantarkan mereka pada penguasaan sebagian besar tanah Palestina. Cita-cita Zionis untuk mewujudkan Negara Yahudi yang berdaulat seolah hanya tinggal menghapus nama Palestina dari ingatan dunia. Di sisi lain, Palestina tidak pernah tinggal diam melihat tanahnya dirampas oleh kaum Zionis. Mereka berjuang untuk mendapatkan kembali tanah kelahiran mereka. Perjuangan rakyat Palestina selalu menemui jalan buntu mengingat Israel memiliki dukungan Negara super power Amerika Serikat. Setiap upaya otoritas Palestina di panggung dunia PBB, selalu dijegal oleh veto Amerika Serikat.

Indonesia memainkan peran penting dalam mengawal konflik yang terjadi antara Israel dan Palestina. Indonesia telah mengambil peran yang tidak bisa diremehkan dalam memperjuangkan hak-hak rakyat Palestina. Indonesia telah memainkan peran co-sponsor, fasilitator, mediator, partisipator, inisiator, aktor, motivator dan justifikator dalam membantu menyelesaikan konflik Israel-Palestina.

\section{DAFTAR PUSTAKA}

BBC News. 2014. "Hamas-Israel Gencatan Senjata.” 2014. http://www.bbc.com/indonesia/du nia/2014/08/140826_hamas_israel _gencatan_senjata.

Burdah, Ibnu. 2014. Islam Kontemporer, Revolusi dan Demokrasi. 1 ed. Malang: Intrans Publishing.

Fisher, Shimon, Dekha Ibrahim Abdi, Jawed Ludin, Richard Smith, Sue Willliam, dan Steven William. 2000. Working with Conflict: Skill and Strategies for Action. London: Zed Books.

Friedman, Thomas L. 1990. Dari Beirut ke Jerussalem. Diterjemahkan oleh Busoni Sondakh dan Ardy Handoko. Jakarta: Erlangga.

Galtung, Johan. 1976. “Three Approaches to Peace: Peacekeeping, Peacemaking and Peacebuilding." Dalam Peace, War and Defense: Essays in Peace Research, 2:282304. Copenhagen: Ejlers.

Garaudy, Roger. 2000. Mitos dan Politik Israel. Jakarta: Gema Insani Press.

Hakiem, Lukman. 2017. "Hubungan Bersejarah Indonesia dan Palestina." Republika Online. 27 Juli 2017. https://republika.co.id/share/otq3p 0385 .

Hermawati. 2005. Sejarah Agama dan Bangsa Yahudi. Jakarta: Raja Grafindo Persada.

Kementerian Luar Negeri Republik Indonesia. 2019a. "Isu Palestina." Kementerian Luar Negeri Repulik Indonesia. 26 Maret 2019. https://kemlu.go.id/portal/id/read/ 
23/halaman_list_lainnya/isupalestina.

—. 2019b. "Indonesia Serukan Penghentian Pembangunan Pemukiman Illegal Israel Di Palestina." Kementerian Luar Negeri Republik Indonesia. 10 Mei 2019. https://kemlu.go.id/portal/id/read/ 251/berita/indonesia-serukanpenghentian-pembangunanpemukiman-illegal-israel-dipalestina.

. t.t. "Isu Palestina." Kementerian Luar Negeri Republik Indonesia. Diakses 28 Desember 2017. https://www.kemlu.go.id/id/kebija kan/isu-khusus/Pages/Isu-

Palestina.aspx.

Maulani, Z.A. 2002. Zionisme: Gerakan Menaklukkan Dunia. 2 ed. Jakarta: Penerbit Daseta.

Media Indonesia. 2017. "Aksi Bela Palestina." 18 Desember 2017. https://mediaindonesia.com/editor ials/detail_editorials/1245-aksibela-palestina.

Noor, Yusliana. 2014. Sejarah Timur Tengah (Asia Barat Daya). Yogyakarta: Ombak.

Purnamasari, Niken. 2017. "Konflik 'Berdarah' Tak Berujung IsraelPalestina di Al-Aqsa." detiknews. 24 Juli 2017. https://news.detik.com/berita/d3571269/konflik-berdarah-takberujung-israel-palestina-di-alaqsa.

Ramdhani, Jabbar. 2017. "Menlu Ajak Yordania Perkuat Dukungan untuk Palestina di KTT OKI." detiknews. 11 Desember 2017. https://news.detik.com/berita/d3765123/menlu-ajak-yordaniaperkuat-dukungan-untukpalestina-di-ktt-oki.

Sihbudi, Riza. 1993. Bara Timur Tengah. Bandung: Mizan.
1997. Indonesia-Timur Tengah: Masalah dan Prospek. Jakarta: Gema Insani Press.

\section{Menyandera Timur} Tengah. Bandung: Mizan.

Suhartiningtyas. 2014. "Analisa Kebijakan Presiden Abdurrahman Wahid Untuk Membuka Hubungan Diplomatik dengan Israel dalam Upaya Peduli Perdamaian Palestina-Israel." Jurnal Analisis Hubungan Internasional 3: 84156. 